\title{
Marketing as Innovation Strategy in Non Profit Sector in China: The Network of Influence "Guanxi”
}

\author{
Antonia Sajardo Moreno, Marta Gil Ibañez, Rafael Curras Perez \\ University of Valencia, Valencia, Spain
}

\begin{abstract}
In a globalized world, not only the business market is overlapped but also marketing models take shape within economic systems. While there has been a proliferation in the implementation of marketing in the private sector, this paper provides a useful entry point for the understanding role of marketing within the nonprofit sector focused on China, the second worldwide economic power. A number of senior managers and directors from different Non-Governmental Organizations (NGOs) were interviewed of what they understood marketing to be and how they considered and implemented marketing within organizational strategy. The findings showed that while marketing was identified as an interesting and influential concept, Chinese nonprofit managers generally had a limited understanding of a marketing theory. The article further discusses reasons behind the dynamic based on personalized networks of influence used and the potential implications for nonprofit entities in China, a sector that plays a very noteworthy role in transformative economies.
\end{abstract}

Keywords: nonprofit organizations, sustainability, marketing mix, China, competitive environment, networks of influence, guanxi

\section{Introduction}

There have been critics of the expansion of marketing beyond its traditional private sector origins from the beginning (Andreasen, 1994). However, everyday marketing is understood as a corporate philosophy more than a synonym for vending or advertising. The majority of nonprofit organizations are selling their ideas and their organization's mission. However, the proliferation in the implementation of marketing in nonprofit sector has not been as leading as it has been in the private sector. In this sense, this paper provides a useful entry point for the understanding role of marketing within the nonprofit sector, taking China as example. It is believed that this is the first paper aimed at marketing focus within the Chinese nonprofit sector.

China is experiencing a rapid transition from a centrally planned economy to the one which is predominantly a free and open market. Thus, it is one of the reasons that make more warranted research attention (Zhou, Chao, \& Huang, 2009). As the authors denoted, the context provided by China is a good context for a study of nonprofit organizations as the traditional mode of operations with the government in firm control. The nonprofit third sector is not exception in this context of change. In recent years, there has been a

Antonia Sajardo Moreno, Ph.D., Department of Applied Economy, University of Valencia, Valencia, Spain.

Marta Gil Ibañez, Ph.D. student, Economy Department, University of Valencia, Valencia, Spain.

Rafael Curras Perez, Ph.D., Department of Marketing, University of Valencia, Valencia, Spain.

Correspondence concerning this article should be addressed to Antonia Sajardo Valencia, Department of Applied Economy, University of Valencia, Valencia, Spain. 
significant increase in the number of nonprofit organizations working in China, local, or international (Hsu \& Hasmath, 2014). Since the beginning of reforms in 1979, NGOs have grown rapidly (Lu, 2007). At this point, one of the organizational aspects, which best reflects the increasing complexity and professionalization of the third sector in China is the marketing management focus adopted by these organizations.

In a country with restrictive policies on the third sector, with problems of motivation for employees of nonprofit organizations, with an extreme dependence on government at all levels, with very specific political and cultural characteristics, and in constant search of a new way allowing them to maintain a high level of growth, management and innovation capacity of the third sector appears as a sustainable alternative to address the social problems of a country with nearly 1,400 million people. In this sense, it is not enough to overcome the challenge adapting these organizations to theories from studies in Western countries (Ming \& Peifeng, 2004). As Lu (2007) denoted, currently, the studies of local NGOs in China tend to go to two extremes: the macro political theories, such as civil society focused on explaining the actual behavior of NGOs or the management theories which have evolved from studies in western countries. In both cases, it is not enough to overcome the challenges faced by these organizations in China. Thus, it is necessary to focus the research on the main variables which concern the country as the restrictive government NGO policies, the motivational problems of NGO staff, their dependent relationship with the state, and some features of China's political culture.

Are the Chinese NGOs implementing a marketing focus within their strategy? What are the attitudes of the stakeholders towards them? Are Chinese NGOs with overseas relations more likely to implement a stable global marketing strategy? The aim of this paper is to explore the level of awareness and knowledge of marketing in nonprofit sector in China. The principal contribution of this paper is to analyze how Chinese NGOs balance personal relations and their willingness to raise awareness. For nonprofit organizations, a strong image is strategic to raise community awareness, thus growing and keeping a strong image through marketing will increase support for the entity.

\section{Literature Review}

\section{Nonprofit Sector in China}

Organizations start out in the limitations of a single person to carry out, easily and efficiently, all the tasks required producing a good or service (Lowental, 1995). In them, it depends on the group efforts to achieve the goal. The humanity gathers thousands of records related to organizations which have channeled the general and social interest, solidarity, and altruism in favour of the most vulnerable and disadvantaged economically social groups, identifying needs and implementing responses of different sign for their satisfaction (Sajardo \& Chaves, 2006). In order to promote initiatives of solidarity directed toward producing and distributing social goods or merit, the citizens' movement is going through a considerable growth. As pointed out by Gracia (1995), Table 1 shows the characteristics that define the organizations in general.

At this point, it can be concluded that organizations are, basically, a set of people with resources who carry out a series of activities in order to achieve a particular goal in a structured and coordinated way. Thus, the organizations are set as the starting point for NGOs.

Since the beginning of the reforms in China in 1979, the emergence of the NGO sector in the country has been the consequence of the changes experimented by the state and the society ( $\mathrm{Lu}, 2007)$. Since then, in the country, there have been a lot of issues and challenges calling for citizens to organize in order to articulate and 
pursue shared interests (Chen, 2006). Thus, NGOs have increasingly become a significant factor in the changing social landscape in China (Hsu \& Hasmath, 2014). China has a special social sector really different from the western concept. As Yu and Qiang (2009) described, Table 2 below shows the classification of the Chinese social enterprises within the country.

Table 1

Characteristics of Organizations

\begin{tabular}{|l|l|}
\hline Group of people & They are composed of a defined group of people who have a purpose to fulfill. \\
\hline Psychosocial systems & $\begin{array}{l}\text { They are psychosocial systems: the people working within them interacting with each } \\
\text { other and with the environment. }\end{array}$ \\
\hline Structure & They maintain an integration of structured activities. \\
\hline Knowledge & Use special knowledge and skills to carry out their activities. \\
\hline
\end{tabular}

Source: personal compilation.

Table 2

Classification of Chinese Social Enterprises

\begin{tabular}{|l|l|l|l|}
\hline $\begin{array}{l}\text { Legal forms of } \\
\text { social enterprises }\end{array}$ & Registered as & Profit distribution & Government intervention \\
\hline $\begin{array}{l}\text { Social welfare } \\
\text { enterprises }\end{array}$ & $\begin{array}{l}\text { For-profit } \\
\text { organization }\end{array}$ & $\begin{array}{l}\text { Being allowed to use profits for } \\
\text { technological improvement, production } \\
\text { scale, capital, and employee welfare }\end{array}$ & $\begin{array}{l}\text { - Annual investigation } \\
\text { - Managerial guidance } \\
\text { - Being required to promote democratic } \\
\text { management } \\
\text { - Being monitored by grassroots } \\
\text { organizations and employees }\end{array}$ \\
\hline $\begin{array}{l}\text { Civilian-run } \\
\text { non-enterprise } \\
\text { units }\end{array}$ & $\begin{array}{l}\text { Nonprofit } \\
\text { organization }\end{array}$ & $\begin{array}{l}\text { - No direct regulation } \\
\text { - Using surplus profits according to the } \\
\text { charter of the organization }\end{array}$ & $\begin{array}{l}\text { Annual investigation mainly focusing on } \\
\text { legitimacy, activities, and revenue }\end{array}$ \\
\hline Cooperatives & $\begin{array}{l}\text { For-profit } \\
\text { organization }\end{array}$ & $\begin{array}{l}\text { Allocating surpluses to the members of } \\
\text { cooperative according to the methods } \\
\text { agreed upon by the members }\end{array}$ & $\begin{array}{l}\text { - No significant supervision } \\
\text { - Being required to form a governing body, } \\
\text { a legal representative, a supervisory } \\
\text { committee, and managers }\end{array}$ \\
\hline $\begin{array}{l}\text { Civilian-run } \\
\text { educational } \\
\text { institutions }\end{array}$ & $\begin{array}{l}\text { For-profit } \\
\text { organization }\end{array}$ & $\begin{array}{l}\text { Reinvesting for better educational activities } \\
\text { and conditions }\end{array}$ & $\begin{array}{l}\text { - No significant supervision } \\
\text { - Being required to form a board of trustees } \\
\text { and directors }\end{array}$ \\
\hline
\end{tabular}

Source: Yu and Qiang (2009).

This research focuses on the second group: the civilian-run non-enterprise units, which is the unique group registered as nonprofit organization in China. Regarding their current situation in the country, it is important to stand out the position of the Chinese government, who is following international trends and promoting the third sector development in a mixed social welfare system. In addition and as part of that welfare system, the quantity and proportion of social services provided by NGOs are increasing (Fisher, Li, \& Fan, 2012). In this way, the organizations need a full collaboration of the government and rely on them to implement their projects (Lu, 2007). Moreover, the Chinese government has created a semi-official NGO sector since the 1990s. Government and Communist Party Departments have been setting up foundations and other organizations to advance charitable, research, information, and policy objectives. These organizations are commonly called “GONGOs” (Government Organized NGOs) (Chen, 2006).

However and although most authors agree on the rapid growth of the sector, there are inconsistencies among those who offer more accurate figures. Chen, Pan, and Wu (2006) mentioned that the Chinese nonprofit sector has expanded from roughly 6,000 registered groups in 1999 to about 150,000 in 2005. In the same year, 
Chen (2006) described the China's NGO community as the group composed by the autonomous NGOs and GONGOs, being the last ones which belong to the government. Based on the statistics from the Ministry of Civil Affairs, Chen (2006) suggested that officially registered NGOs in China numbered 244,700. Nevertheless, the total number of self-governing autonomous NGOs is unknown. Ultimately, Hsu and Hasmath (2014) mentioned that in the last three decades, approximately, 440,000 officially registered NGOs have emerged, standing out the high number of unregistered ones as well. Therefore, it cannot be concluded the exact number of organizations operating in China, but the positive growth that these organizations are experiencing is clear and consistent. Regarding their legal regulation, nowadays there are two regulations in force: the 1998 Regulations on the Administration of Social Organizations and the 2004 Regulations on the Administration of Foundations. The numerous conditions launched by both laws are contributing to maintaining social stability by keeping out those that government perceives as a threat and to keep the NGO sector weak and relatively small. Besides, with all this preoccupation with regulating NGOs activities and behaviour, there is the possibility that the state does not effectively use their potential (Hsu \& Hasmath, 2014). Currently, the Chinese government through the Ministry of Civil Affairs issued draft registration and management regulations for public comment for those regulations, including the new Charity Law and the Overseas NGO Law, too, which will go into effect in January 2017.

\section{Marketing as a Tool for Management}

Marketing's definition has experienced an evolution for a time. To see this evolution and be able to understand it, it is useful to pay attention how its definition has been changed. For that, the definitions offered by the American Marketing Association (AMA) throughout history are taken into account:

- 1960: "Marketing is the result of business activities that direct the flow of goods and services from producer to consumer or user";

- 1985: "Marketing is the process of planning and executing the conception, pricing, promotion and distribution of ideas, goods, and services to create exchange and satisfy the objectives";

- 2004: "Marketing is an organizational function and a set of processes for creating, communicating, and delivering value to customers and for managing customer relationships to benefit the organization and its stakeholders";

- 2013: "Marketing is the activity, set of institutions, and processes for creating, communicating, delivering, and exchanging offerings that have value for customers, clients, partners, and society at large”.

In relation with the typology, based on different criteria appear different types of marketing (Vazquez, 2004). As it is displayed in Figure 1, there are different typologies of marketing depending on the main agent of exchange.

This research considers, and in depth studies, the second group as it takes into account everything related to nonprofit sector. To continue, another classification appears based on the exchange object (Vazquez, 2004). On one hand, the marketing of goods and services is the one with which it is possible to make a contribution and collaborate. On the other hand, social marketing works to create changes or adopt an associative behavior. Thus, this research takes into account both of them as both cases can be used by nonprofit organizations. So, it can be concluded that this paper focuses on three specific types of marketing: nonprofit or altruistic, marketing of goods and services, and social marketing. 


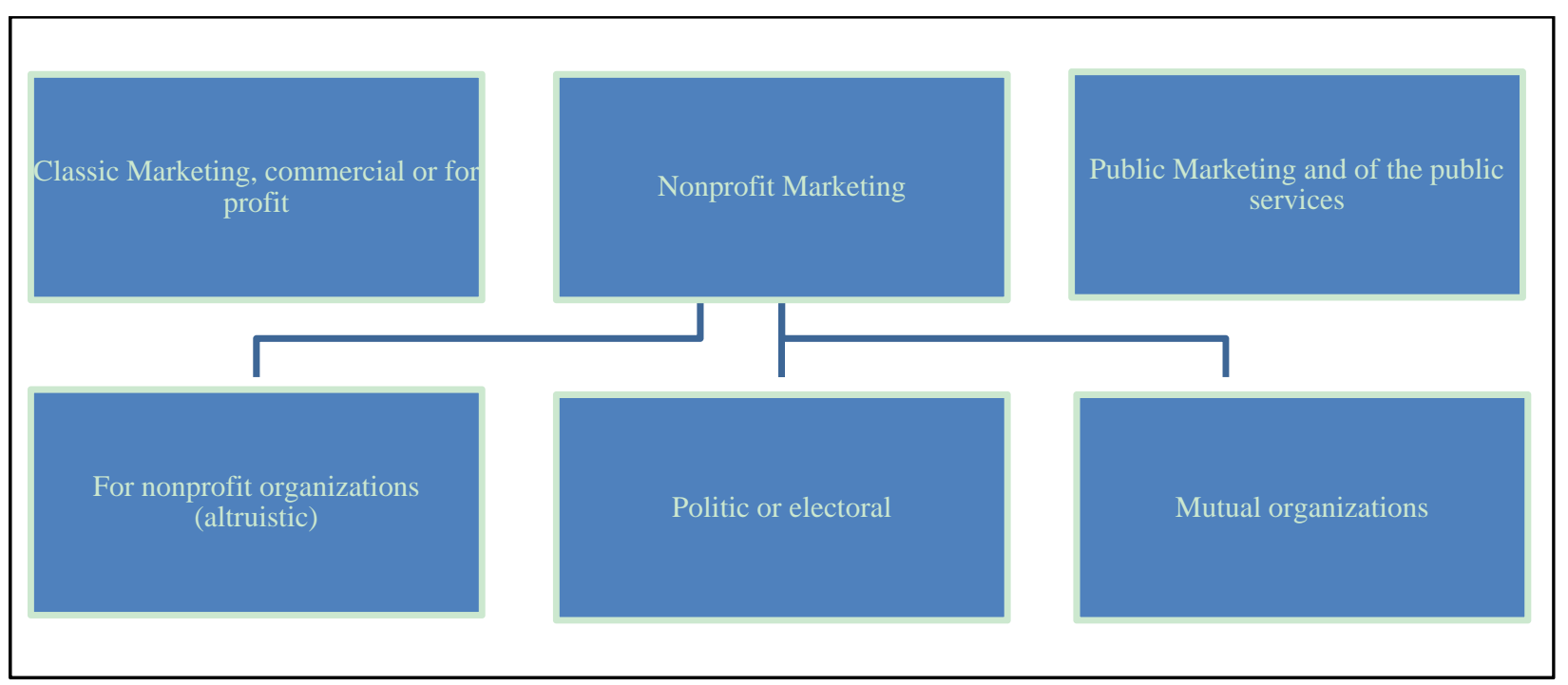

Figure 1. Typology of marketing depending on the main agent of exchange. Source: Vazquez (2004).

The application of marketing is the best way for nonprofit organizations to get a higher satisfaction level from their users, which would guarantee a constant budget (Kotler, Amstrong, Saunders, \& Wong, 1999). However, to a large extent, nonprofit organizations make use of marketing tools if they are more concerned about the needs of its customers than for the function they perform, that is to say, the product they sell (Santesmases, 2004).

Currently, marketing mix is one of the predominant ideas in modern marketing. It supposes the set of controllable tactical marketing tools that a company blends to produce a desired response from its target market (Kotler, Armstrong, Saunders, Wong, Miquel, Bigné, \& Cámara, 1999). As appeared in Table 3, marketing mix is divided into four groups of variables known as the "four Ps": product, price, place, and promotion.

Table 3

The Four P Components of the Marketing

\begin{tabular}{|l|l|}
\hline Variable & Components \\
\hline Product & Product variety, quality, design, features, brand name, services \\
\hline Price & List price, payment period, discounts, allowances, credit terms \\
\hline Promotion & Sales promotion, advertising, sales force, public relations, direct marketing \\
\hline Place & Channels, coverage, assortments, locations, inventory, transport \\
\hline
\end{tabular}

Source: Kotler and Keller (2006).

The four Ps represent the sellers' view of the marketing tools available for influencing buyers (Kotler \& Keller, 2006). At the end, the marketing mix consists of everything the firm can do to influence the demand for its product (Kotler, Armstrong, Saunders, Wong, Miquel, Bigné, \& Cámara, 1999). Currently, they are the same in a profit or nonprofit vision. However, there are some aspects which make the difference between the marketing mix used in nonprofit organizations and profit organizations. It entails the transfer of concepts, methods, and techniques of business marketing to nonprofit vision. Thus, the marketing mix for nonprofit organizations could be defined as:

- Product: mostly, the product is the program and service offered. Nonprofit organizations are not product-driven, they are mission-driven. The name recognition is important in the nonprofit sector and can 
enhance marketability (Wolf, 1999). Nonprofit organizations have an "organization-centered" marketing mindset and may falsely believe that their product or service is needed by the market (Andreasen \& Kotler, 2003).

- Price: it helps to establish the perception of the value for one product or service. For nonprofit organizations, price supposes what it costs or sacrifices to participate in. A consumer attempting to distinguish two organizations in the same field may sometimes conclude that the one whose price is higher actually offers the better product or service (Wolf, 1999).

- Place: the location at which the product, service, and program are made available to the customer. Many nonprofit organizations have come to understand if customers, clients, or constituents cannot or will not come to their headquarters, the organization must take the product or service to them (Wolf, 1999).

- Promotion: promotion of the product, program, or service (Wolf, 1999). Usually, nonprofit organizations can promote their image, products, and programs through different options: media campaign, conferences, etc. Commonly, these organizations do not designate too many resources to this field and they use free media.

In nonprofit sector, successful marketing strategies allow the organization to achieve its mission, get their scheduled goals, and achieve financial stability in the long term (Wolf, 1999). Many nonprofits still deny the existence of competition, feeling that this is just a feature of the private sector, thinking that organizations with similar activities are simply partners in the provision of social services, not competitors. Indeed, developing a proper marketing mix system for products and services is as important in the nonprofit world as it is among profit companies. Although researchers appear to largely agree that the adoption of a market oriented perspective is important for nonprofit organizations (Andreasen \& Kotler, 2003), it can be argued that market orientation is not relevant for nonprofit organizations because as explained before, their mission (product) is defined in advance and cannot be changed in dependence of market needs. To end with that, it is important to concrete some of the general benefits of implementing a marketing orientation in nonprofit organizations:

- Discipline to assess the necessities and wishes of all of its publics;

- Analysis habits: internal and external;

- Improving coordination and integration of functional units;

- Diversification of funding sources;

- More effective way to communicate the ideas, values, and social behaviours of the organization;

- Managing the public image of the organization;

- Better control of the activities cost;

- Better control of effectiveness of its actions.

\section{Research Methods}

\section{Research Design}

The purpose of this research is to define the current status of the use of marketing tools in NGOs in China to understand the characteristics, motivations, and strategic behavior. Furthermore, the analysis assesses the degree of awareness of the existence of such tools in the nonprofit sector and how its use impacts on society. In this sense, the study analyzes in a real context to examine the situation of real organizations. Therefore, it is a descriptive study that considers 10 cases. The senior managers and directors from these 10 organizations 
were interviewed in 2013 following a structured questionnaire developed as a tool to collect data. The interview enclosed predetermined questions suggested by marketing literature (Andreasen \& Kotler, 2003; Kotler \& Keller, 2006). It should be noted that, especially in the most local and small organizations, the information was not systematized and standardized. However, interviews allowed discussing about emergent matters and themes not included a priori on the questionnaire. As Bulla and Starr-Glass (2006) pointed out, this approach contributed to an exploration less driven by precise hypotheses and more concerned with emergent themes.

As seen in the previous section, the current number of nonprofit organizations working in China is uncertain. However, high percentage of authors agrees on the number of organizations working in the country, over 100,000 groups. For that reason, this project was developed as an initial survey. The restricted number of entities interviewed limits the consistency of the findings and decreases the extent to which they can be generalized. Thus, the research stands as a starting point for a more comprehensive and deeper study on marketing in social sector in China.

\section{Sample}

The 10 NGOs interviewed in China were selected after a deep analysis of nonprofit entities based on Shanghai. Choosing different profiles and the willingness to take part in the research were keys in the selection process. Those selected were considered suitable to bring knowledge about the topic under investigation. The 10 NGOs work in a range of different areas. Based on the International Classification of Nonprofit Organizations, $40 \%$ of the sample works on social services, $20 \%$ in relation with education programs, and the other $40 \%$ left over on different fields, including mental health, law and legal services, voluntarism promotion, and environment.

It is important too to stand out the main features shared among all the organizations. In this way, it will be possible to observe and delimit what type of organization this research is focused on. First, the 10 organizations are working as a nonprofit organization, but they are not all registered with this concrete legal form. As showed before, in China, the non-enterprise units are the unique group officially registered as nonprofit organization. So, $70 \%$ of the sample is registered as non-enterprise unit in China mainland, $10 \%$ as non-enterprise unit in Hong Kong, and the $20 \%$ left over is registered as business company in China mainland. Thus, it shows that the distinction between registered organizations and unregistered is real and currently still happens in China.

In the background, it has pointed out the relation maintained with the Chinese government. Thus, 100\% of the sample considers the Chinese government as an element of the organization and all of them to a greater or lesser extent stand out the good and close relation with them.

Last, the answers obtained in relation with the use of marketing as a tool for management of the organization in general demonstrate the real situation in China, $50 \%$ of the sample considers the use of marketing as a professional practice, meanwhile the other $50 \%$ does not consider this use. However, it derives from the lack of awareness about what is exactly marketing and the benefits it entails. Thus, some organizations which firstly have answered that they do not use marketing tools have showed up after some practices in this field. The 10 organizations taken into account by this research are located in the city of Shanghai. However, some of them are also developing projects in different cities around the whole country. The NGOs are shown in Table 4. 
Table 4

\begin{tabular}{|c|c|}
\hline NGOs & Introduction \\
\hline $\begin{array}{l}\text { Stepping Stones } \\
\text { stepping } \\
\text { ing }\end{array}$ & $\begin{array}{l}\text { Stepping Stones was founded in } 2006 \text { by long-term Shanghai expatriate Corinne Hua in } \\
\text { response to requests from principals of migrant schools in Shanghai, which struggle to } \\
\text { provide a reasonable standard of English teaching to the students in their schools. } \\
\text { Currently SS recruits, trains, coordinates, and supports around } 200 \text { volunteers to teach } \\
4,000 \text { students in } 20 \text { migrant schools and community centres in Shanghai. }\end{array}$ \\
\hline $\begin{array}{l}\text { Shanghai Xingyu Community } \\
\text { Development Center }\end{array}$ & $\begin{array}{l}\text { Shanghai Xingyu Community Development Center is a social work organization } \\
\text { registered in November 2009. Its mission is enabling the community to become a stage } \\
\text { for the public to share their wisdom. Through the participation and contributions of } \\
\text { volunteers, the community will become more warm and harmonious. Its goals are to use } \\
\text { specialized social work concepts and methods to promote community development, to } \\
\text { encourage more people to pay attention, enjoy, and participate in public interest work. } \\
\text { Currently, the organization works with several thousand of beneficiaries. }\end{array}$ \\
\hline $\begin{array}{l}\text { prise Research Center } \\
\text { Social Enterprise } \\
\text { Research Center } \\
\text { 社会企业研究中心 }\end{array}$ & $\begin{array}{l}\text { Social Enterprise Research Center (SERC) focuses on local social enterprise research, } \\
\text { education, and training. Founded in 2008, SERC has finished over } 80 \text { local social } \\
\text { enterprise case-studies, several fundamental research papers and launched first Social } \\
\text { Enterprise White Paper in Boao Asia Forum. }\end{array}$ \\
\hline $\begin{array}{l}\text { Shanghai Enrichment Community } \\
\text { Service Centre }\end{array}$ & $\begin{array}{l}\text { Initiated by NPI since 2008, Shanghai Enrichment Community Service Center } \\
\text { (Wulixiang) was founded with the goal of replacing estrangement in communities with } \\
\text { acquaintance. Replying on the hosting of public services equipment, the center attempts } \\
\text { to build a platform for the development of community services stations, which can } \\
\text { integrate social resources, offer comprehensive services for all residents and maximize } \\
\text { the efficacy of public services equipment. From its founding to March 2010, Wulixiang } \\
\text { has hosted many public service stations. }\end{array}$ \\
\hline $\begin{array}{l}\text { Shanghai for NGO Legal service } \\
\text { centre (ForNGO) }\end{array}$ & $\begin{array}{l}\text { ForNGO was established in September 2011. Their main activities are hosting } \\
\text { workshops and providing legal services to other NGOs. The founders of ForNGO are } \\
\text { lawyers who wish to promote the development of People Republic of China NGO-related } \\
\text { law through their research and interaction with other NGOs. Its mission is to establish a } \\
\text { social nationwide platform of legal services and support to promote the development of } \\
\text { the community. Currently, they are working with around } 500 \text { beneficiaries. }\end{array}$ \\
\hline $\begin{array}{l}\text { Hands On Shanghai } \\
\text { 牵手上海 }\end{array}$ & $\begin{array}{l}\text { Hands On Shanghai was founded in } 2004 \text { by a group of young professionals. With } \\
\text { previous experience with the HandsOn/Cares worldwide network, they established an } \\
\text { affiliate organization in Shanghai. Hands On Shanghai believes that it can empower the } \\
\text { people to take actions to make the community and the larger world better-healthier, } \\
\text { greener, more prosperous and equitable, better informed and educated, less vulnerable to } \\
\text { disasters, and more civil and hospitable. Its mission is to promote volunteerism, inspire, } \\
\text { equip, and mobilize people to take action to change the world. They envision a world in } \\
\text { which everyone has discovered their power to make a difference, creating healthy } \\
\text { communities with vibrant, participatory societies. So far, Hands On Shanghai has } 10,600 \\
\text { registered volunteers with } 15,408 \text { volunteers hours contributed. }\end{array}$ \\
\hline $\begin{array}{l}\text { ird Hotline for Migrant } \\
\text { s }\end{array}$ & $\begin{array}{l}\text { Little Bird was established in June } 1999 \text { in Beijing and the branch offices were } \\
\text { established in April 2006, October 2006, and June } 2011 \text { in Shenzhen, Shenyang, and } \\
\text { Shanghai respectively. Little Bird is a nonprofit organization dedicated to providing free } \\
\text { services to migrant workers in reclaiming their unpaid wages, providing urban } \\
\text { integration training and legal counseling. Its mission is defending the migrant workers' } \\
\text { rights. With more than } 14 \text { years of history, Little Bird has helped the workers get back } \\
\text { their deferred salary for RMB183,418,370. Actually, Little Bird is registered as a } \\
\text { company but in fact it is a non-profit organization, offering free service to the migrant } \\
\text { workers. Moreover, they stand out their good relation with the government. }\end{array}$ \\
\hline
\end{tabular}


Table 4 continued

\begin{tabular}{|c|c|}
\hline NGOs & Introduction \\
\hline $\begin{array}{l}\text { The Art from Heart } \\
\text { 心公艺䒔蚪由 艺㭬 }\end{array}$ & $\begin{array}{l}\text { heArtS is a Chinese local NGO supporting people with Special Needs in improving their } \\
\text { confidence, connecting with their communities, and gaining social recognition through } \\
\text { the art as a way to educate and improve their quality of life. By setting up workshops and } \\
\text { providing training programs in communities, they provide them free arts courses and } \\
\text { focus on their families as well. heArtS is an NGO dedicated to eliminate social prejudice } \\
\text { and exclusion toward the Special Needed, through free art courses, self-confidence } \\
\text { rebuilding and social interaction for them and their families. So far, they work in five } \\
\text { cities in China (Shanghai, Beijing, Shenzhen, Guangzhou, and Hangzhou) with more } \\
\text { than } 500 \text { beneficiaries. }\end{array}$ \\
\hline Shanghai CSW\&MSM Center & $\begin{array}{l}\text { Shanghai CSW\&MSM Center (SCMC) is a nongovernmental and nonprofit organization } \\
\text { focused on the rights and health of the vulnerable and minority sexuality groups. SCMC } \\
\text { works to improve their survival environment and provide a better medical and legal } \\
\text { service. In addition, SCMC cooperates with academic institutions, massive media, and } \\
\text { other social institutions. Its mission is improving the survival environment of the } \\
\text { vulnerable and minority sexuality groups. SCMC works with Shanghai Fudan University } \\
\text { School of Public Health, Georgetown University, China \& Gates Foundation Project, and } \\
\text { Shanghai Municipal Center for Disease Control and Prevention, among others. }\end{array}$ \\
\hline Shanghai Root & $\begin{array}{l}\text { The Shanghai branch of Roots \& Shoots was founded as a volunteer organization in } \\
\text { November 1999. Five years later, in November 2004, Roots \& Shoots was granted a } \\
\text { nonprofit organization status by the Shanghai City Government. Their program aims to } \\
\text { foster respect and compassion for all living things, to promote understanding of all } \\
\text { cultures and beliefs, and to empower and inspire individuals to take action to make a } \\
\text { positive difference in world. Its goals are to implement positive change through active } \\
\text { learning about, caring for, and interacting with the environment, to demonstrate care and } \\
\text { concern for all animals, to enhance understanding among individuals of different } \\
\text { cultures, ethnic groups, religions, socio-economic levels, and nations through its global } \\
\text { communication network and to help young people develop self-respect, self-confidence, } \\
\text { and hope for the future. Roots \& Shoots activities focus on the three areas of the } \\
\text { program: care and concern for the environment, care and concern for animals, and care } \\
\text { and concern for the community. }\end{array}$ \\
\hline
\end{tabular}

\section{Research Results}

\section{Product}

In the case of nonprofit organizations, the product is the program and services offered. In this case study, all the organizations have well defined their product, as shown in Table 5 all of them are capable of defining their main activity in one sentence.

Therefore, the sector does not matter as all their missions and visions are well defined and clear announced. Along these lines and paying attention to the information presented above, it can be concluded that a big majority of the organizations are not product-driven but mission-driven.

\section{Price}

In the case of the price, the research focuses its attention on the information about the price of the general project more than what it costs to participate. Therefore, this information considers the cost of the total project and the budget directed towards marketing. In this way and to be capable of seeing the size of the organizations, it is important to stand out that the average budget amount is roughly 500,000 Chinese Yuan (CYN) annually, almost 71,500 Euro (€) $(7 \mathrm{CYN}=1 €)$. 
Table 5

Organizations Involved in Case Study and Its Main Activity

\begin{tabular}{|l|l|}
\hline Organization & Main activity \\
\hline Stepping Stones & To teach English in Shanghai's migrant schools and community centers. \\
\hline $\begin{array}{l}\text { Shanghai Xingyu Community } \\
\text { Development Center }\end{array}$ & $\begin{array}{l}\text { Social work organization which promotes the community development and encourages } \\
\text { people to pay attention to public interest work and participate in them. }\end{array}$ \\
\hline Social Enterprise Research Center & Research organization focused on local social enterprise research, education, and training. \\
\hline $\begin{array}{l}\text { Shanghai Enrichment Community } \\
\text { Service Centre }\end{array}$ & To provide professional service and community-building. \\
\hline $\begin{array}{l}\text { Shanghai for NGO Legal service } \\
\text { centre (ForNGO) }\end{array}$ & To host workshops and provide legal services to other NGOs. \\
\hline Hands on Shanghai & Platform for volunteers activities. \\
\hline $\begin{array}{l}\text { Little Bird Hotline for Migrant } \\
\text { Workers }\end{array}$ & To provide consultation services to migrant workers and defend their rights. \\
\hline heArtS Volunteer Team & Free art courses to people with special needs. \\
\hline Shanghai CSW \& MSM Center & $\begin{array}{l}\text { Organization focused on the rights and health of the vulnerable and minority sexuality } \\
\text { groups. }\end{array}$ \\
\hline Shanghai Roots and Shoots & $\begin{array}{l}\text { Ambassadors to care for animals, community, and the environment through a grassroots } \\
\text { youth-driven movement of R\&S clubs in schools. }\end{array}$ \\
\hline
\end{tabular}

Source: personal compilation.

Regarding the budget aimed at marketing, only $40 \%$ of the sample keeps in mind marketing when they develop the annual budget, $60 \%$ left over does not take into account this item which is pushed into the background from the beginning. Data are more interesting by dividing the information according to the legal form of the organizations. Thus, it is observed that $100 \%$ of the entities registered companies do not allot any budget aimed at marketing. Regarding non-enterprise unit (NEU), half of them has budget aimed at it.

So, it can be concluded that the organizations have a considerable size and more than half of them do not consider the use of marketing as useful as they do not establish a budget directed towards it. However, even most of them do not have this budget, it is observed that usually they make use of marketing tools and therefore, they do it without knowing.

\section{Place}

The place means the location where the product is made available for the customer. To develop a proper distribution system for products and services is as important in the nonprofit world as it is among profit companies. In this case, on one hand, $90 \%$ of the sample markets their project directly, only $10 \%$ uses intermediaries as the main way to do it; on the other hand, only $30 \%$ of the sample makes use of policies of merchandising meanwhile the $70 \%$ left over does not consider its use as a practice which contributes to increasing the sales. In this case, the use of merchandising increases the visibility of one organization, the sense of belonging, and the possibility to involve more people in the project. Thus and as a result of this research, seven of each 10 organizations in China are not using this technique to place their program.

\section{Promotion}

One of the most important things in promotion is the communication. It points to two different groups: internal (staff) and external (sponsor and beneficiaries). In this way, the communication is higher when it occurs more often and through personal means. Related to the sample of this research, it can be noted that there exists a balance between the external and internal communication used by the sample, so no one prevails over the other. 
To continue, currently, it seems like all the organizations and even people should have a website. Thus, it is odd to think that one organization does not use this tool of communication and more if it is nonprofit. At present, it has been set up as useful and low price tool to communicate and stay in touch with all the stakeholders. However, the statistics of this research surprise with their results one more time. About $80 \%$ of the sample has own website meanwhile the $20 \%$ left over does not have.

Continuing with the promotion, it is important to stand out the use by the sample of the corporate image. At the end, all the organizations show their logo and slogan at different places. To a greater or lesser extent, all the organizations use their corporate image to illustrate their activity. Anyway, at this point, it is important to highlight the existence of the choice to do it or not and also the quantity of money it supposes. For example, the cost to provide uniform to all the volunteers is not comparable with the cost of the documentation or identification at office. Thus, the total of the sample takes into account the importance of standing out its corporate image and they agree on some tools, as it is shown in Figure 2.

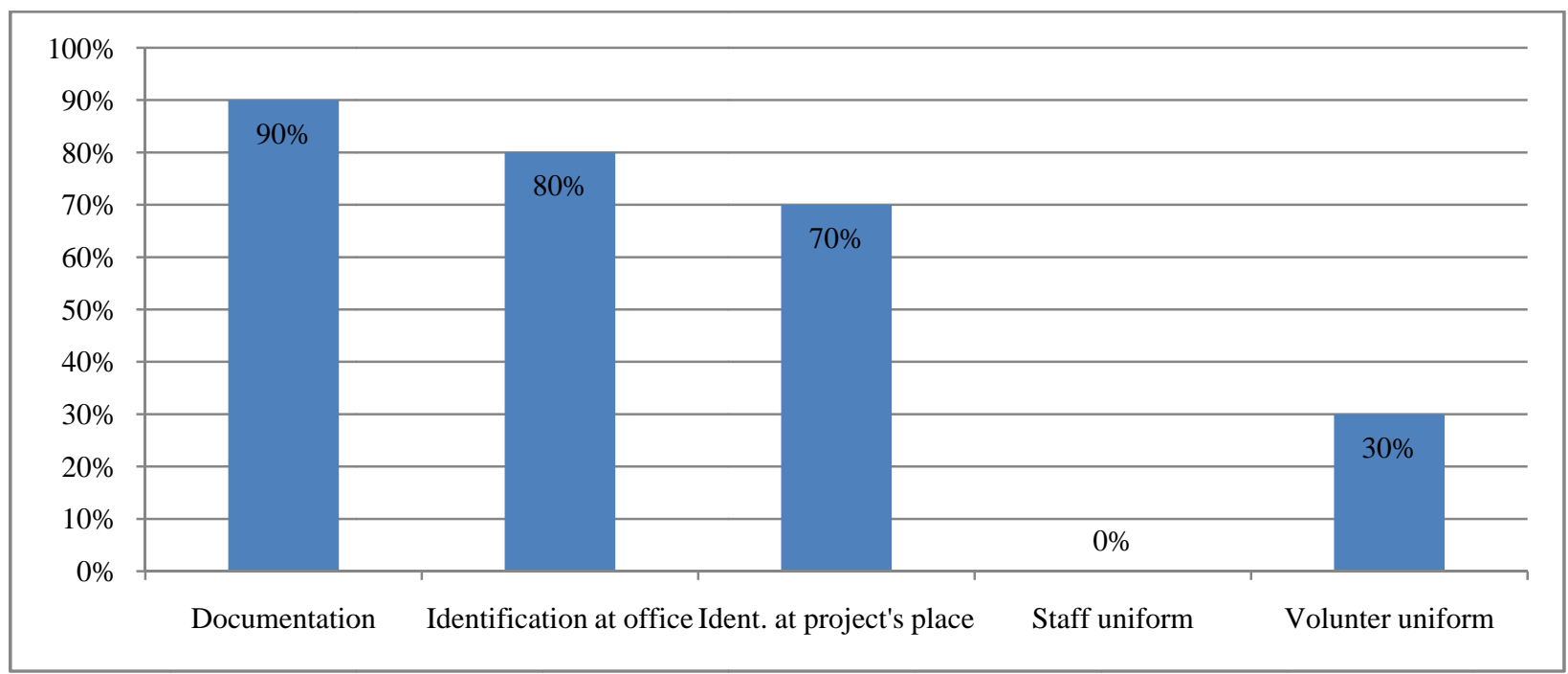

Figure 2. Use of corporate image in case study (\%). Source: personal compilation.

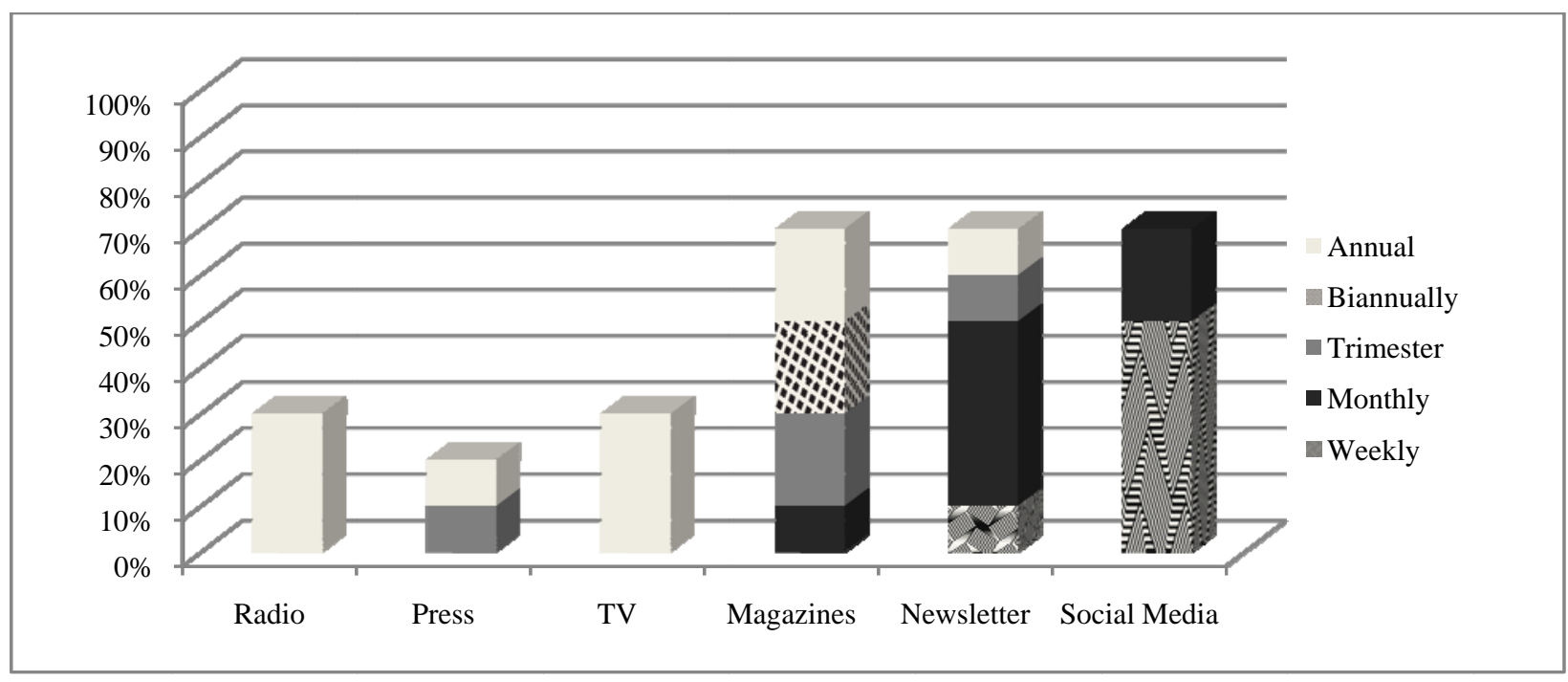

Figure 3. Use of advertising in case study (\%). Source: personal compilation. 
To end, except $20 \%$ of the sample who did not answer these questions, $100 \%$ left over, who supposes $80 \%$ of total sample, uses advertising to promote its activity and it is always unpaid. As of the data collected, the most common way to do that is through magazines, sending of a newsletter and updating news on social media. Secondly, on TV or radio and press is the less used. As shown in Figure 3, the regularity is not the same. Regarding social media, the weekly update prevails over the rest and the most used tool is Weibo. Relative to newsletters, the monthly update prevails over the rest. So, the most used tool is social media compared to everything else. Last, the regularity about magazines is not shared by the sample as it can be annual, biannual, trimester, or monthly.

\section{Analysis}

Thanks to the data collected with the sample, it can be deduced that some points in order to accomplish the main goal proposed at the beginning make a conclusion about the real situation of the use of marketing in nonprofit sector in China. Thus, extrapolating the information from the study to the reality provides some points which could define the profile for a NGO in China:

- A NGO in China maintains a good relation with the Chinese government;

- A NGO in China has a good definition of its product. It means that the organization knows what is its main activity and is capable of expressing it in one sentence;

- A NGO in China markets it project directly;

- A NGO in China uses its corporate image to promote its project and activity;

- Four for every five NGOs in China have their own website;

- Four for every five NGOs in China use advertising to promote their activity;

- One for every two NGOs in China considers that it does not use marketing as a tool for the management of the organization;

- Almost one for every two NGOs in China has a budget aimed at marketing;

- Almost one for every three NGOs in China implements policies of merchandising.

So, the key point to stand out by this case study is the lack of awareness of the marketing concept in the nonprofit sector in China. The organizations' analyses have shown that although they make use of different tools in an intuitive way, they do not know the tools belong to the marketing approach. In relation with the four Ps' analyses and as appeared in Figure 4, it can be concluded that the organizations pay more attention to the issues linked to the product and the promotion. Secondly, they pay attention to the place and last to price. Thus, the priorities followed by them can be established like that as follow.

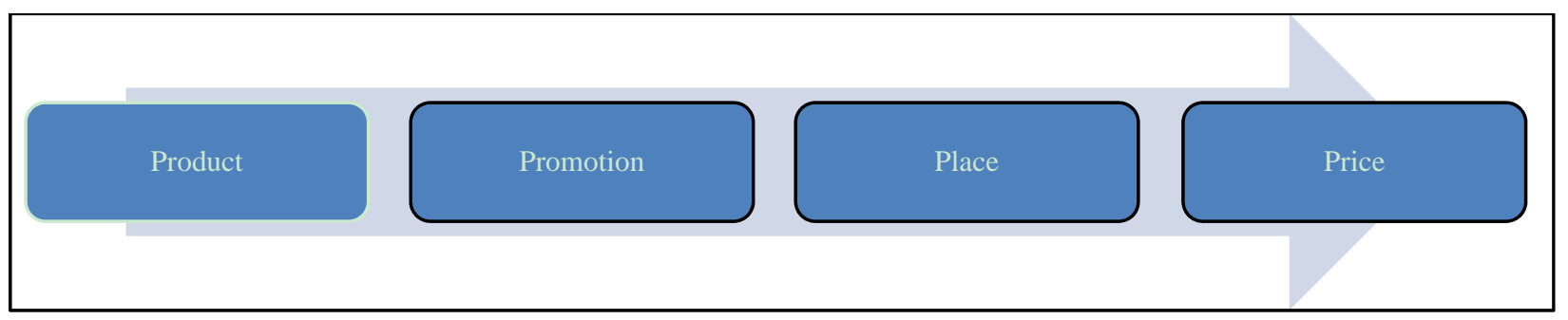

Figure 4. Prioritization of the use of marketing tools in NGOs in China. Source: personal compilation.

In addition, it should be noted that a datum pointed out in all the questionnaires: $80 \%$ of the sample thinks that the most effective way to promote the services offered by them is the personal relations. It highlights in a 
sector where the most common thing is to try to raise awareness and involve as many people as possible. Anyway, it is a specific feature of Chinese culture and finally, this cultural and social element could benefit the market expansion and competitive positioning, but do not impact or enhance internal operations.

\section{Discussion, Conclusion, and Implications}

China is experiencing a rapid transition from a centrally planned economy to one which is predominantly a free and open market. From a business point of view, China has turned into the second economy in the world. As Bulla and Star-Glass (2006) pointed out, economic systems are characterized by distinctive assumptions, patterns, and mechanisms of exchange. Marketing models take shape within these economic systems. While there has been an increase in the adoption and utilization of marketing in the private sector, this research's main interest is in the extent to which marketing is understood and used by nonprofits focused into China. Currently, in Chinese nonprofit sphere barely there is institutional development and it is still far from developing in the forms of governance and management of organizations in the third sector.

At present, non-enterprise unit is the unique legal form of social enterprise able to register as nonprofit organization in China. However, some organizations are working under other legal forms, including as a business company. Relating to the size of Chinese nonprofit sector, it could not be concluded the total number of self-governing autonomous NGOs is working within the country. But and even with that, the positive and exponential growth experienced by this group in China is clear and consistent. Thus and although the political power in this sector is still one of its pillars, NGOs have increasingly become a significant factor in the changing social landscape in China.

Linked with the growth of the sector, its complexity turns up. In this sense, one of the organizational aspects which best reflect that complexity and its professionalization is the marketing management focus adopted by nonprofit organizations in China. Little by little, they have got used to use the perspective and techniques of marketing to achieve their goals. However, it is not as part of a global marketing strategy, but they just take advantage of the opportunities which show up. As the data collected, one for every two NGOs in China considers that it does not use marketing as a tool for the management of the organization and has not a budget aimed at it. As of the data collected, it has been observed that most of the organizations which do not have this budget or think they are not adopting marketing strategy, usually make use of its tools. Therefore, they do it without knowing. So, it has been proved that at least half of the entities are unaware of the marketing concept and consequently of the benefits its application may generate.

Some of the organizations which have taken part in this research are not working only within China. Some of them are a branch established in China, but they belong to a bigger structure which works outside the country as well. Relative to that, the organizations which maintain these relations are more willing to implement marketing focus in the management of the NGO. In those cases, sometimes the organizations count with international staff or volunteers who can provide them an open and ample point of view. It does not mean that if one organization involves foreign people it will implement marketing focus in its management. But, is has been observed that organizations more involved and in relation with other countries are more likely to use marketing tools.

In addition, it has been possible to discover one of the key points in China regarding the relations and communication. As previously pointed out, most of the nonprofit organizations in China believe that the most effective way to promote their services is the personal relations. Even if one organization tries to raise 
awareness as much as possible in the society, they still believe that the personal relation is the most convenient way to achieve sustainability. In Chinese, there is one word to make reference to this dynamic based on personalized networks of influence, it is guanxi (关系). As Park and Luo indicated (2001), guanxi is embedded in every aspect of Chinese social life and Chinese firms develop it as a strategic mechanism to overcome competitive and resource disadvantages by cooperating and exchanging favors with competitive forces and government authorities. It makes no difference between profit and nonprofit sector: at the end, guanxi is something needed and important in China. Of course, it does not mean that when an organization has guanxi it does not need to do anything else. But it means that if an organization has this network, it will easily achieve its goals in a sustainable way. So, it has been observed that the impact of marketing on the fundraising resources is positive but it is not conclusive yet.

To sum it up, this research shows that NGOs in China occasionally use marketing focus as a tool for management; even without adopting a stable global marketing strategy. One of the reasons which appear in response to this phenomenon is the needs experienced by these organizations. That is, if an organization has well defined its product and its financing needs are covered, it might be that the organization does not contemplate the use of an integrated marketing focus. Moreover, it has to highlight the link between the use of marketing tools and the results obtained in nonprofit organizations. Therefore, it is concluded that if its awareness and use increase, the results and benefits evidenced by the organizations proportionally would increase as well.

It is justified to demonstrate, contrast, and build on the trend followed by the third sector in other economies, in order to discover and develop an international technical innovation tool adaptively depending on the needs. Case in point, checking the consistency of marketing is treated as a strategy of innovation in the nonprofit sector in China. However, it is not possible to extrapolate and adapt those methods to other contexts because each country has a unique management model. In this sense, China is a particular case. With a population of roughly 1,400 million people (World Bank, 2016) ${ }^{1}$, a 7\% annual economic growth (World Bank, 2016) and a capitalist system led by a single Communist Party and insurmountable social gaps, turn the country into a very special and unique case. In short and despite the progress, China is hardly the basis about which to develop an international tool or model of marketing in nonprofit sector.

Ultimately, the investigation brings to light different topics to use in future investigations. The existing information gap about the legal regulation of NGOs in China, the different channels used by the current organizations to overcome these difficulties, the case of international NGOs working within China, the lack of coordination between marketing and guanxi or in-depth study of the necessities required by Chinese organizations are some of the lines of investigation which arise to continue working on it. So, this research answers a variety of questions but at the same time it opens new ones to continue investigating and studying thoroughly.

\section{References}

Andreasen, A. R. (1994). Social marketing: Its definition and domain. Journal of Public Policy \& Marketing, 13(1), $108-114$. Andreasen, A. R., \& Kotler, P. (2003). Strategic marketing for non-profit organizations (6th ed.). New Jersey: Prentice-Hall. Bulla, M., \& Star-Glass, D. (2006). Marketing and non-profit organizations in the Czech Republic. European Journal of Marketing, 40(1/2), 130-144.

\footnotetext{
${ }^{1}$ www.worldbank.org (July 2016).
} 
Chen, J. (2006). The NGO community in China. China Perspectives, 68, 29-40.

Chen, M. Y. T., Pan, L. J., \& Wu, H. (2006). Developing China’s non-profit sector. The McKinsey Quarterly, 3, 1-6.

Fisher, K. R., Li, J., \& Fan, L. (2012). Barriers to the supply of non-government disability services in China. Journal of Social Policy, 41(1), 161-182.

Gracia, L. (1995). Introducción a la teoría administrativa. Valencia, Venezuela: Alfa.

Hsu, J., \& Hasmath, R. (2014). The local corporatist state and NGO relations in China. Journal of Contemporary China, 23(87), 516-534.

Kotler, P., Armstrong, G., Saunders, J., Wong, V., Miquel, S., Bigné, E., \& Cámara, D. (1999). Introducción al marketing. Madrid: Prentice-Hall.

Kotler, P., \& Keller, K. L. (2006). Marketing management (12th ed.). New Jersey, USA: Pearson Prentice Hall.

Kotler, P., Amstrong, G., Saunders, J., \& Wong, V. (1999). Principles of marketing (2nd ed.). New Jersey, USA: Prentice Hall Europe.

Lowental, J. (1995). Reingeniería de la organización. México: Panorama.

Lu, Y. (2007). NGOs in China: Development dynamics and challenges. Discussion Paper 18, China Policy Institute. University of Nottingham.

Ming, W., \& Peifeng, L. (2004). Minjian Zuzhi Tonglun (A general survey of nongovernmental organizations). Beijing: Shishi Publishing House.

Park, S. H., \& Luo, Y. (2001). Guanxi and organizational dynamics: Organizational networking in Chinese firms. Strategic Management Journal, 22, 455-477.

Sajardo, M. A., \& Chaves, R. (2006). Balance y tendencias en la investigación sobre tercer sector no lucrativo. Especial referencia al caso español. CIRIEC-España, Revista de Economía Pública, Social y Cooperativa, 56, 87-116.

Santesmases, M. (2004). Marketing. Conceptos y estrategias (5th ed.). Madrid: Editorial Pirámide.

Vazquez, J. L. (2004). Pasado, presente y futuro de las dimensiones pública y social en el desarrollo conceptual del marketing. International Review on Public and Nonprofit Marketing, 1(1), 9-34.

Wolf, T. (1999). Managing a nonprofit organization in the twenty-first century. New York, USA: Simon \& Schuster Inc.

Yu, X., \& Qiang, Z. (2009). Development of social enterprises under China’s market transition. EMES International Conference.

Zhou, Y., Chao, P., \& Huang, G. (2009). Modeling market orientation and organizational antecedents in a social marketing context. Evidence from China. International Marketing Review, 26(3), 256-274. 